\title{
Hegemonic Challenges of Iran and Russia in the Transcaucasia Region
}

\author{
Mohammad Sadegh Yahyapour ${ }^{1} \&$ Mosayeb GharehBeygi ${ }^{2}$ \\ ${ }^{1}$ Sowmesara Branch, Islamic Azad University, Sowmesara, Iran \\ ${ }^{2}$ Kharazmi University, Tehran, Iran \\ Correspondence: Mohammad Sadegh Yahyapour, Sowmesara Branch, Islamic Azad University, Sowmesara, Iran. \\ E-mail: Ms.yahyapour@yahoo.com
}

Received: June 6, 2016 Accepted: June 27, 2016 Online Published: June 29, 2016

doi:10.5539/jpl.v9n5p289 URL: http://dx.doi.org/10.5539/jpl.v9n5p289

\begin{abstract}
The Caucasus is perhaps best described as a mosaic of peoples ancient and modern intertwined across a complex, often inaccessible geography that has made it a crossroads linking not only east and west but equally north and south. The aim of this paper is to enhance the understanding of future Iran and Russia challenges in Transcaucasia. Russian post-Soviet geopolitics invokes Eurasianism as its inner rationale and meaning, as a greater good that imbues pragmatic, interest based politics with a sense of mission. Although Russia remains a strong regional power with firm position on international level it is still hard for Moscow to accept loss of the position of great power. The methodology of this research is descriptive-analytical and it attempts to give a geopolitical answer to the question that how Iran can gains a hegemony in the Transcaucasia region?
\end{abstract}

Keywords: Iran, Russia, Transcaucasia, hegemony

\section{Introduction}

During the lifetime of the Soviet Union, the great powers were limited in the Caspian region. Caspian was only under the influence of Soviet, due to Soviet dominance to the large part of the Caspian Sea and unwillingness of United States of America to conflicts With Soviet and in the other side, the recognition of superpowers spheres of influence by each other. Hence, there was relative stability in the region. But after the collapsing of Soviet, several powers attended in the Caucasia region. Thus, while before the collapsing of the Soviet, a dominant power makes integrity and stability in the region, after the collapse of the Soviet Union, provided the tendency for Competitions and challenges in the region (Smith, 2005: 13). Historically, the Transcaucasia states -Armenia, Azerbaijan and Georgia- has served as a trade corridor and arena for competition between the Russian, Turkish, and Iranian empires (Kaplan, 2014: 3). While Transcaucasia states were not independent until the early 1990s, they have spent the last two decades establishing themselves as states, and are more concerned with internal security and territorial and sovereignty disputes than with broader regional struggles. The location of the Southern Caucasus has determined much of their states foreign strategies and policies. Situated at the crossroads of Asia and Europe, Iran and Russia, these states have been involved in great power struggles since the days of the Mongol expansion (Misera, 2013: 3). But all three states entered the post-Soviet era entangled in conflict. Armenia and Azerbaijan warred over Nagorno Karabakh, an autonomous oblast that had been located in Azerbaijan in Soviet times but was ethnically predominantly Armenian. Between 1988 and 1994, the two states fought to a destructive stalemate, leaving Nagorno Karabakh and surrounding regions under Armenian control. The war left both economies exhausted and created significant numbers of displaced persons, to the point that both took over a decade to recover their pre-war GDP per capita. But this region has significant role in the universal power equations. Located on the peripheries of Persia, Turkey, and Russia, it has been for centuries an arena for political, military, religious, and cultural rivalries and expansionism; the resulting movements have influenced the ethnic composition of the population, which is extremely complex and rich in customs, languages, economic activities, and patterns of land use.

Collapse of the Soviet Union was the most important upheaval of the second half of the 20th century that opened up new dimensions for security and national interests of the Islamic Republic of Iran. At the end of the 1980's and early 90's three important events helped Iran to develop relations with its South Caucasian neighbors. Simultaneously, ending of the "cold war" and the rise of New Independent States (NIS) changed Iran's 
geopolitical attitude towards the North. Besides, new security threats were just rising, such as conflict between Armenia and Azerbaijan, escalation of internal territorial conflicts in Georgia. While political processes at Iran's Western border limited its ability to conduct active policies, situation at its northern border opened up not only opportunities but threats. Under enormous pressure from its young population to achieve economic progress, and in result of increasing instability in the region, Iran drew its attention to its northern neighbors (Chitadze, 2012: 5). However, Iran has not been successful in the gaining hegemony in the Transcaucasia region. Partially, this is due to the influence of the West in the region and having more attraction of the West to the three countries of Transcaucasia and, well, playing down of Iran geopolitical potentialities in its foreign policy. In this paper, we attempt to study of Iran geopolitical potentialities and its congruency with three states of Transcaucasia. It seems that if Iran foreign policy consider the geopolitical potentiality, can have more influence in the region. Iran geopolitical potentialities include important and determining aspects in culture, linguistic, strategy, history and energy.

\section{Methodology}

This research is a qualitative and applicative research. The method used in this paper is descriptive-analytical. Required information has been collected through library resources, including books, magazine articles, newspapers, Internet, etc.

\section{Background and Review of Literature}

Iran, geographically, is located in South-West Asia which is nearby with Central Asia, the Caucasus, parts of the Middle East, Persian Gulf and South Asia. Iran geopolitical capabilities is such sufficient and necessary that it can with relying on these capabilities convert itself into a influencing power in the Transcaucasia region in the upcoming future.

\subsection{Geopolitics}

With its long and distinguished line of adherents and proponents, geopolitics ranks among the oldest and most recognizable bodies of written political theory. Yet it has atrophied in the modern era to such an extent that while almost everyone is acquainted with the term, scarcely anyone uses it correctly and fewer can precisely define it. In the United States, for example, geopolitical events are popularly understood to be issues and actions that take place overseas. The term 'geopolitical' is so broadly construed as to be meaningless. This lamentable conceptual degeneration is due almost entirely to the defeat of the Axis powers in World War II. Nazi misuse of geopolitical theory through the German school of Geopolitik, as a purposeful guide and moral justification for their particular brand of racist militarism, made post-war geopolitical studies - whatever perceived merits it may have once had-an academic taboo subject (Dolman, 2005: 11). At this point, it seems that geopolitics can be define with three interactive element of power, politics and geography (Hafeznia, 2011:37). In this point, geopolitics can be refer to the hegemony, policy and heterogeneity. In other words, geopolitics based on the interaction of three element -power, politics and geography- is an optimum scale for foreign policy planning and decision making. The consequences of three sort of geopolitics id than an exploration of geopolitics and foreign policy that can be located within broader scaffolding of identity formation, state sovereignty and territorial congruency. Therefore, hegemony gains in mutual relations of geopolitics and foreign policy; that is to say that potentialities of territory (spatial-temporal) emerge with political power and in this way, foreign policy acquires more interest and spheres of influence in national aspect.

\subsection{Hegemony}

Hegemony is a system in which an individual or group has strong, unofficial leadership over everyone else, with the consent of weaker parties. In this paper, the concept of Hegemony is not exactly based on the Antonio Gramsci perspective. According to Gramsci the dominant class who owns agents of production has no guarantee to rule. For leadership and to rule dominant class tries to get the support from other social classes. Dominant class provides this support with hegemony. Besides dominant class knows that with misinforming subordinate classes they cannot provide support, so they compromise with subordinate classes. Hegemony is not a rule which leads by force and repression. The foundation of hegemonic society should be considered. The foundation is not just based on capital and cash resources but also moral, cultural, ideological surroundings. These surroundings build states historical background and the social content of political fight. But, what we conceptualize from hegemony is the multitude as its operative capacity of political category and conceives it both as a limit to state power and as the locus of democratic practice (Emerson, 2013: 428). Such a concept not only disavows politics itself as the space of antagonism and a struggle for Antonio Gramsci's hegemony, but also recognizes a mutually understanding for interactive relations. The model 1 explains the framework of this research. 


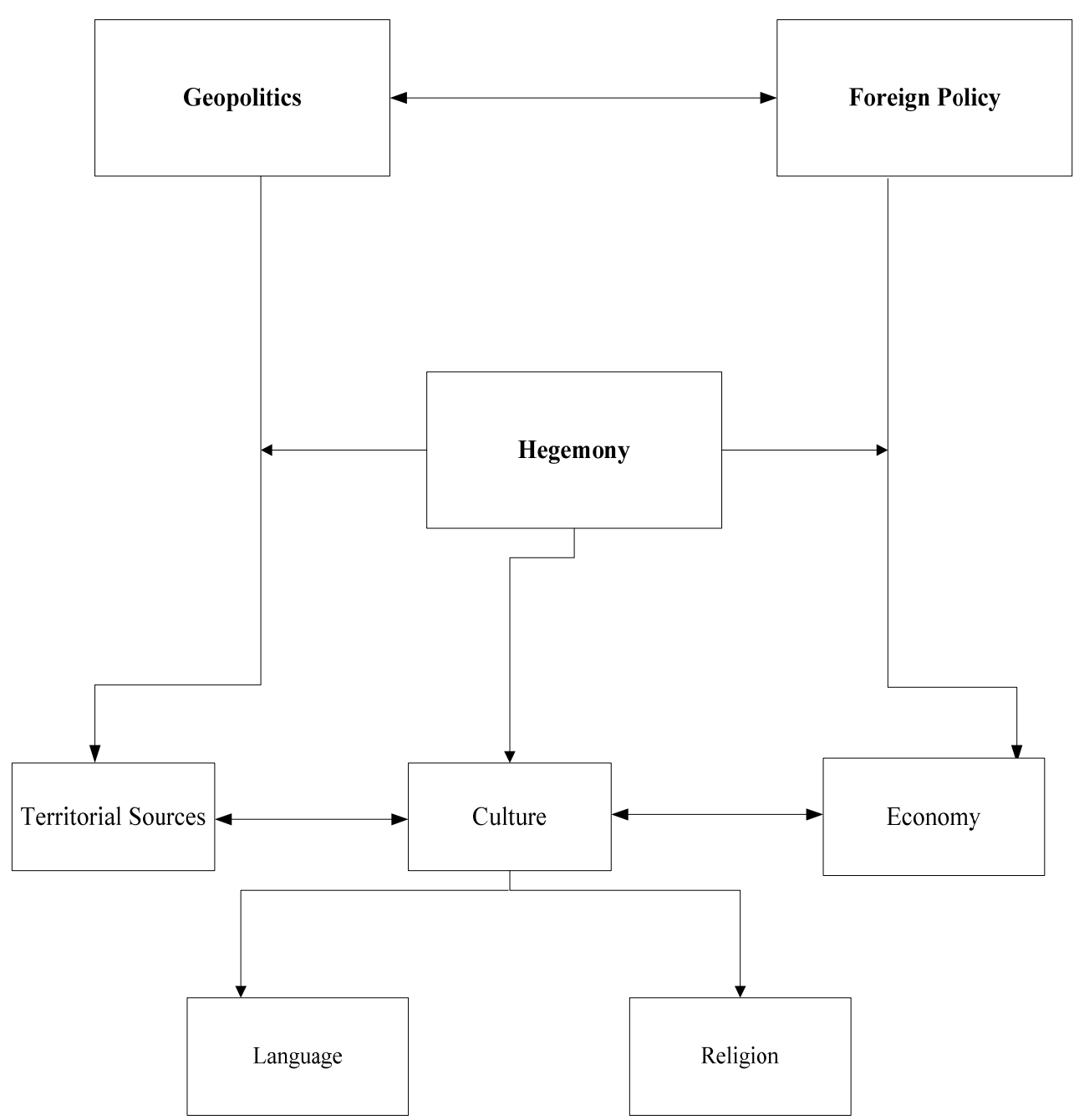

Model 1. The mutual relation of geopolitics and foreign policy in the scaffolding of hegemony (Rabiee and GharehBeygi, 2015)

\subsection{Geopolitical Hegemony in Russia’s Foreign Policy}

\section{Politics of Russia}

Specification in geographic, ethnic and religious characteristics of Russia Made to the foreign policy ideas and different approaches pursued at different periods in the country. In general, the post-Soviet Russian foreign policy can be divided into three categories:
1- Westernism
2- Eurasianism
3- Centralism

1) Westernism: Tendency to West in Russian foreign policy has a long history. According to this idea, Russian needs the West for the development in the economy, culture and democracy and this gives a special place to Russia in the international system. This thought dominated on politics Russian from 1991 to 1996. In these years, West was considered as a friend and Islam as an enemy (Sharaf Alzia: 2008, 88). This approach, after the Soviet collapse and in the Boris Yeltsin period performed as an uncontrollable process. During this period, Russia's strategy based on two principles:

a) Complete trust to the international economic institutions for economic development

b) Optimism to cooperation with the West in foreign policy

This politics continued from the Cold War to the end of the Yeltsin period. They hoped with setting aside Marxist 
ideology, have entered a new stage of the strategy With West particularly the United States. But With economic crisis of 1988 Kosovo, crisis and most importantly NATO enlargement to the East Exacerbate suspicions towards the West and led to the end of the period (Vaezi:2010, 4).

2) Eurasianism: Based on the Eurasianism, Russia is an Asian and European country and according to the West has been ignored the interests of Russia in Asia. Therefore, interaction and relationship with Middle Eastern countries should be considered. According to this perspective, Russia is a great power and has perpetual benefits not perpetual friends. Opposition to mono-polarity in international system and America's unilateralism is a version of this perspective (Sharaf Alzia: 2008, 2). Eurasianism theory is not only anti-Western or anti-democratic, but also According to Sergei Stankovic, member of Council of Russian foreign policy emerged in order to make a balance between the extreme eastern and western trends And has not errors of the Gorbachev period that considered extreme Westernism and radicalism theory like "common European home" (Beygi and Motaharnia: 2009, 262).

3) Centralism: This perspective has evolved form of nationalism (opposition against Westernism minded, willing to Eurasianism) that invigorated at the period of President Putin. The main characteristics of this cohort is the realism and pragmatism, who believe that Russia has no permanent friends and enemies and they do anything (even negotiating with the enemy) for interests of Russia. The priority of economy is logic of centralism and they try by absorbing investments and transfer of technology to increase the power of the Russian economy due to the Russia's economic problems (Forsberg, 2004).

\section{Area of Study}

Transcaucasia, a small but densely populated region to the south of the Caucasus Mountains. It includes three independent states: Georgia in the northwest, Azerbaijan in the east, and Armenia situated largely on a high mountainous plateau south of Georgia and west of Azerbaijan (britanica.com). Together these countries have an area of about 71,850 square miles (186,100 square kilometers). Transcaucasia, also known as Southern Caucasia, is bounded on the north by Russia on the east by the Caspian Sea on the south by Iran and Turkey and on the west by the Black Sea.

\section{Findings}

\subsection{Geopolitical Hegemony of Russia in the Trans-Caucasia}

In 1991 the Soviet Union collapsed, But Russia influencing on the world, especially in Central Asia and the Caucasus did not disappear. Russia as the widest and most advanced industrial country in the Caucasia has a special position. Russia through the Black Sea and the Baltic accesses to the Pacific and Siberia and according to oil and gas resources in Siberia and the export pipeline system, are less dependent on Caucasia basically (Lo, 2002, 18-24).

While the newly independent republics from the Soviet Union, depend on the Russia, The leaders of the Caucasia countries consider the development of its hydrocarbon resources as a foundation for economic prosperity. But these countries are surrounded by land and they have to transport their oil and natural gas through a pipeline which crosses several international boundaries. The pipeline pathways in the Caucasia region, was designed to link the internal regions of the former Soviet Union. Russia has tried with the preserve the traditional pathways of energy transferring from its territory, prevented the Caucasia countries, influence of the West and particularly America as well as (Dabiri: 1999, 87). Of course, Russia do not intended to conflict with the West in no way, rather is trying to cooperation with the West to achieve the interests. In fact, Russia regarded the West as an opportunity and through Sovereignty over the Central Asia and the Caucasus as leverage, uses from Western countries to obtain further interests and advantages (Karami: 2005, 64). Russia has aligned its interests with the West after the Soviet collapse in various reasons which most common reasons are:

1) Russian weakness in economy against the economic power of West

2) Require investment from Western companies in the region

3) Having similar European cultural background and intellectual history

4) Confronting with terrorism and attempting to avoid the influence of Islamic fundamentalists in the region

But, some issues caused a problem in making the alignment with West:

- Supporting the European governments from governments which tended to Western democracy in this region 
- The emergence of numerous regional crises, such as the crisis in Chechnya, Georgia and Europe posturing against the Russia

- NATO expansion to the East and joining of East European countries to the EU which Russia regards it as a security threat

- Enlargement of oil companies operations and domination over the economy by American and European investors in the region (Heydari and Mohammadi: 2006, 3).

From a Russian point of view, the Caucasia area is of particular concern due to a host of interests that must be protected. Among the most important are (Timothy, 2000: 75):

- Geo-strategic interests: Russia wants to remain strong in the area and wield power within and control over the Commonwealth of Independent States (CIS), thereby ensuring the security of its southern flank. States of concern here are those CIS members noted above plus Georgia and Armenia. Russia sees as its greatest danger the potential expansion of Chechen authority into Dagestan at Russia's expense, thereby severely restricting Russia's direct access to the Sea (only Astrakhan remains).

- Geo-political interests: the retention of Russian influence within the space of the former Soviet Union directly determines the future of Russian statehood, according to many analysts. Caucasia oil, despite all its economic significance, is merely the external manifestation of the global political task of the present day-the restoration of Russia's might. Evolving problems in the North Caucasus among the autonomous Russian republics (not only Chechnya, but also Karachay-Cherkessia, Kabardino-Balkaria, North Ossetia, Ingushetia, etc.) and growing religious pressures (from the Wahhabis, among other groups) make this area as or perhaps more important to Russia than the CIS in terms of interests and stability.

- Economic interests: Russia wants to ensure that cash flows in the form of Western capital will continue from Central Asian and Siberian oil fields, and that cash flows are not be redirected out of Russia and into the Caucasia region. Russia can compete on a level playing field with Kazakhstan and other Caucasia oil investors with the proper Production Sharing Agreement (PSA) legislation in place. Another economic concern (which is also a geo-strategic, geo-political and ecological concern) is sovereignty rights to the body of water itself. The bottom and outer edges of the Caucasia is divided one way, the column of water over these divisions in another.

- Ecological interests: developing safe ecological norms for the exploitation of both hydrocarbons and fishing resources (especially the protection of the Caucasia sturgeon stock that produces 80-90 per cent of the world's finest caviar) are paramount concerns. This feeling is especially acute due to the severe meteorological conditions (extremely strong and unpredictable storms) that occur in the North Caucasia region.

Finally, we can summarize the goals and interests of Russia like this:

1) Maintaining the countries in the region depended on Russia

2) Constant dominance over energy resources

3) Preventing from the intrusion of the Western powers

4) Dominating over the region to enhance the credibility of bargaining in order to get advantages from the Western powers

5) Prohibiting of the militarization of the region (due to the presence of NATO and America in the region)

6) Spreading of Russian culture

7) Avoiding from the dominance of competing powers (America, China, Japan, Europe Union)

8) Confronting with radical Islamism

9) Countering to terroristic threats

10) Coping with stress and instability that determined the Security of the Russian

\subsection{Geopolitical Hegemony of Iran in the Trans-Caucasia}

Geographically, Iran, is located in South-West Asia which is nearby with Central Asia, the Caucasus, parts of the Middle East, Persian Gulf and South Asia. Iran as an important country in the region has a special geopolitical potentialities. Iran in comparison with the other countries and especially with Russia can obtain hegemony and penetration in the Transcaucasia region. Iran geopolitical potentialities include important and determining aspects in culture, linguistic, strategy, history and energy. Three stats of Azerbaijan, Armenian and Georgia have a geopolitical congruency with Iran. This congruence is so that can be refer as foundation for foreign policy. In 
following pages, we studied the geopolitical potentialities and contingencies of Iran with each three states of the Transcaucasia region on the perspective of hegemony in foreign policy.

Iran-Azerbaijan: Azerbaijan is one of the most strategic points in the Transcaucasia region which has depth root in Iranian culture. Azerbaijan is a geographical continuation of Azerbaijan Providences in Iran and its assimilation and deep history links between Iran is so obvious (Mojtahedzade, 2001: 403). Iran was one of the first countries to establish full diplomatic relations with Azerbaijan. Following the declaration of the Parliament of Azerbaijan to restore independence of Azerbaijan Republic on October 18, 1991 and in early December 1991, Iranian Foreign Minister Ali Akbar Velayati visited Baku, where he signed a number of agreements on political, economic, and cultural cooperation and pledged to support Azerbaijan's membership in the Organization of the Organization of Islamic Cooperation (Grove, 2012). The most significant index of these countries is contingency in geo-culture and geopolitics of linguistic. Cultural commonalities, especially in the border areas has a growingly importance to establishment of the infrastructure required. Human beings, with culture connect together and create nation with common mental which derives from the same culture.

Ideology overshadowed identity during the Cold War, as the left-right tension drove both the world and domestic politics. The end of the Cold War was associated with an increase in identity-related politics both at the international and at the domestic level. Samuel Huntington published his widely circulated "Clash of Civilizations" article, arguing that post-Cold War international conflicts would be driven by civilizational identities, the most important being Islam and that of the West. Ethnic conflicts and genocides from the Balkans to Africa confirmed the view that identity, whether it is in the form of ethnicity or religion, would be the main source of conflicts in this new era. The September 11 terrorist attacks, with their roots in radical Islamist ideology, further reinforced Huntington's culture-based theory of conflict along 'Islam versus the West' lines. In terms of cultural geography, the Greater Iran covers all parts of Iran Plateau, parts of Central Asia, Balkh and Hindu Kush Mountains along the North-East, Afghanistan and West of Pakistan in the southeast and by the West Iraq and in the northwest the Caucasus. Among the states of the Transcaucasia, Azerbaijan has a deep historical and cultural homogeneous and proximity with Iran (Light and Vukovic, 2011).

Language is a spatial-temporal phenomenon that provides mutual perception and internal consistency. This, in itself, creates a nation that will access to the political consciousness gradually and will form a geographical territory of the state and government. The people of Azerbaijan speak into Turkish language. Iran can utilize this with the spread of and official research about Turkish with the relative hegemony of Iran's Azeri culture and penetrate in these countries with the own geopolitical weights. Turkey is the major geopolitical rival of Iran for hegemony in Azerbaijan. Turkey emerged as a crucial country in the post-Cold War environment. This is because Turkey connects the East to the West, not only geographically but also culturally. It is the only successful democratic, secular and Western-oriented country with a Muslim population. Its moderate understanding of Islam - as well as its religious parties like the AKP or religious schools and orders that tend to hold a more moderate view of Islam when compared to their counterparts in other countries - could be a role model in the Middle East and Central Asia (Murinson, 2012). It is also a NATO ally, debunking the "Christian club" image of the organization. Thus, the end of the Cold War and the emergence of Islamist politics as an international force increased Turkey's importance in the region. Moreover, several Turkic countries (Azerbaijan, Turkmenistan, Kazakhstan, Kyrgyzstan, and Uzbekistan) gained independence with the end of the Cold War. Using its historical, cultural and ethnic bonds, Turkey could play an important role in integrating these countries with the West in politics, economics and culture, especially considering the fact that Iran as alternative to Turkey in providing guidance to them.

Iran-Armenia: two elements of Geo-economy and Geo-culture are tiding these countries to each other. For more than 20 years, Iran has appeared as the main and most reliable ally of the republic of Armenia. Since Iran recognized Armenia's independence on December 25, 1991, the two countries have strengthened their political relationship on many occasions and have committed themselves to realize numerous common projects in the economic field. Within the region, Armenia has the closest ties to Iran (Badalyan and Kusznir, 2011). These relations are based in large part on the two states' isolation, and are conditioned by geographical as well as economical and political realities: Armenia has only two open borders, one of which is with Iran (the other with Georgia), and Iran is eager to develop relations. Strong cultural ties also underlie the bond, as some 90000 ethnic Armenians live in Iranian cities such as Uremia, Tabriz and Jolfa. In Tehran view, the special relationship with Armenia offers a way to evade international sanctions and pursue its nuclear ambitions. It is aimed at struggling against largely imagined Azeri "irredentism" and at weakening Azerbaijan as part of the competition for Caspian Sea's hydrocarbon resources. Taking a position into the Caucasus lastly allows Iran to oppose the 
involvement of the United States and of the European Union in the region and to respond the strategic ambitions of its traditional foes: Turkey and Israel (Collins and Owen, 2012).

Iran supported Armenia in the 1992 war over Nagorno-Karabakh — a semi- autonomous region that is de facto administered by Armenia - and the two have states have always had a significant arms trade as well as a visa facilitation and liberalisation scheme (Rubin, 2012). Nagorno-Karabakh has its own $\mathrm{f}$ inancial and economic infrastructure and could be a future outlet for Iranian investments and illicit trading. It is in Iran's interest that Nagorno-Karabakh remain stable, without further fighting or displacement of people. Instability in the region might upset the large Azeri and Armenian populations living in Iran, or create a refugee crisis that would put further strain on the Iranian economy. In 2002, Armenia's then-Foreign Minister, Vartan Oskanian, said, 'Iran is the guarantor of stability in the Karabakh region (Schaffer, 2003: 20). The two countries have established close ties in all spheres and promoted "effective cooperation" in the fields of energy, sport, nature protection, health care, agriculture, education, science, culture as well as in the interprovincial relations (Ministry of Foreign Affairs of the republic of Armenia, 2012). Armenia is neither a producer of oil nor of natural gas so is highly dependent on imported hydrocarbons. The main suppliers are Russia and Iran but fuel produced from oil is also imported from Bulgaria, Romania and other countries in the Middle East. Russia owns about $80 \%$ of the country generating capacities and therefore Armenia is extremely dependent on Russia. The Argel Gyumush (Sevan-Hrazdan Cascade) hydroelectric power plant and the Hrazdan thermal power plant (the largest in the South Caucasus) were given to Russia as part of payment of national debt (Khachatrian, 2009).

Besides of economy, in cultural aspect Armenia is influenced from ancient Persian culture in such a way that many Persian loan words or words with Persian roots, it can be found in Armenian language. Furthermore, the totality of Armenian culture is influenced by the culture of ancient Iran especially by Zoroastrianism religion (Russell, 1986: 439). Armenians have been a part of numerous empires of Iran from the Achaemenid period and is influenced by the Iranian culture strongly. Indeed, the culture of Armenia is a combination of indigenous, Persian and Hellenistic/Christian cultures (Mohammadi Malayeri, 1997: 84).

Iran-Georgia: geopolitics of culture and economy between Iran and Georgia is so striking that can be frame as a pattern for foreign policy. The eastern Georgian regions of Kartli and Kakheti were Persian Provinces during Sassanid times. Some members of the Georgian elite were involved in the Safavid government and Amin al-Sultan, Prime Minister of Iran, was the son of a Georgian father (Clawson, 2005: 168). Eastern Georgia was under the influence of Persia until 1783. Persia officially gave up claim to parts of Georgia according to the terms of the Gulistan and Turkmenchay Treaties.

Economically, while the new Georgian government has extended its diplomatic hand to Iran — and indeed to all countries in the region - it is not as simply 'pro-Iranian as some western rhetoric suggests. Georgia's approach is also partly a response to the policy of the previous government, which adopted a very western approach, limiting relations with some regional partners and focusing heavily on western contact. Georgia's position is ambiguous: on the one hand expressing a desire to join both NATO and the EU, while on the other pursuing relatively amicable relations with Iran. This amicable relationship is not a geographical imperative: the two countries do not share a border, although they may operate a joint parliamentary 'friendship group' proposed by Georgia's new government to enhance trade relations and bilateral diplomacy beyond the current Intergovernmental Joint Economic Commission.

As it is known from the history, due to the convenient geographic location of Georgia, Iran always had interests towards this South Caucasian country. Gaining control over Georgia was giving an opportunity to Persia to establish contacts with Muslim Khanates of North Caucasus, also in achieving influence on the country, which is located in the crossroads of Europe and Asia and where main trade links were crossing the territory of different Georgian Kingdoms and Principalities. Georgia and the Islamic Republic of Iran have signed 47 bilateral documents, including:

1) Air Transport Agreement between the government of the Islamic Republic of Iran and the government of the Republic of Georgia;

2) Agreement on Reciprocal Promotion and Protection of Investments between the government of the Republic of Georgia and the government of the Islamic Republic of Iran;

3) Agreement between the government of Georgia and the government of the Islamic Republic of Iran for the Avoidance of double Taxation and the Prevention of Fiscal Evasion regarding taxes on income and capital;

4) Agreed Minutes on Economic, Trade, Scientific and Technical Cooperation between the Republic of Georgia and the Islamic Republic of Iran; 
5) Agreement on Trade Cooperation between the government of Georgia and the government of the Islamic Republic of Iran (Chitazde, 2012: 9)

It could be fruitful to emphasize that after abolition of the visa regime between Iran and Georgia in 2010, Iranian investments in Georgian economy have been increased in the fields of property, trade, tourism, transport and restaurant businesses and different joint ventures have been grounded. In the first quarter of 2012, there have been implemented the investments on 247 thousand US dollars. According to the National Statistical Service of Georgia, in the first quarter of 2012, about 13600 citizens of Iran visited Georgia, which prevails the dates of the previous years by $91 \%$ (Iranian Investments in Georgia, 2012: 9).

According to official statistics, volume of the trade between Georgia and Iran in January - April 2012 prevailed 22,6 million dollars. Export from Georgia - 1,6 million dollars, import - 21 million dollars. In 2011, volume of Export from Georgia was 16,2 million US dollars, import - 64,8 million US dollars. (Iranian Investments in Georgia, 2012: 9)

What has been neglected in the relationship between Iran and Georgia, is the cultural dimension between the two countries. It appears that Iran should be combined economy and culture simultaneously to gain hegemony in Georgia.

\section{Conclusions}

Russian post-Soviet geopolitics invokes Eurasianism as its inner rationale and meaning, as a greater good that imbues pragmatic, interest based politics with a sense of mission. Eurasianism as a particular tradition of theorizing Russia's identity and place in the world has a momentum of its own that transcends the pragmatics of Russian post-Soviet foreign policy. Having emerged in the 1980s and 1990s as a political opposition to Gorbachev's New Thinking and to the pro-American shift in Russian foreign policy in the first few years of Boris Yeltsin's tenure, neo-Eurasianism has been gaining increasing influence in Russia, especially since the 1993 parliamentary elections (Ersen, 2004: 135). But, Iran as an important country in the region has a special geopolitical potentialities. Iran in comparison with the other countries can obtain hegemony and penetration in the Transcaucasia region. At present, Russia is the major power in the region. Iran Geopolitical potentialities include significant and definitive aspects in culture, linguistic, strategy, history and energy. Therefore, Iranian foreign policy should act in order to find out the spheres of influence at the countries of the region. Iran, among all the countries of the region has a more prominent geopolitical weight and potentiality that can penetrate even more than Russia in the Caspian and Transcaucasia region, however in the long term. Speaking about Iran's interests in the Transcaucasia, Tehran has repeatedly offered its services in settling the Nagorno-Karabakh conflict. Iran is willing to act as a mediator in this area. Iran maintains quite cautious policy which is non-hostile towards Armenia. This could be expected in terms of good-neighborly Iranian- Azerbaijani relations. Moreover, Iran trades with Armenia, supplying gas and building railways together with transport monopoly Russian Railways. Iran is one of Georgia's most important trading partners and the Intergovernmental Joint Economic Commission is functioning between the two countries. However, Iran has not been successful in the gaining hegemony in the Transcaucasia region. Partially, this is due to the influence of the West in the region and having more attraction of the West to the three countries of Transcaucasia and, well, playing down of Iran geopolitical potentialities in its foreign policy. Therefore, foreign policy of Iran in Transcaucasia shows that Iran rely on one-dimensional relation with three states in the region. Moreover, this relations is not based on the geopolitical potentialities and not mutually and interactive as well as. It seems that if Iran foreign policy consider the geopolitical potentiality, can have more influence in the region. Iran geopolitical potentialities include important and determining aspects in culture (with all three states), linguistic (Armenia and Azerbaijan), economy (all three states) and religion (Azerbaijan, in partial with Armenia). This geopolitical elements must act in Iran foreign policy along and interactive with other factors.

\section{References}

Badalyan, L., \& Kusznir, J. (2011). "Oil and Gas Pipelines in the South Caucasus”, Caucasus Analytical Digest $\mathrm{n}^{\circ} 33$, Center for Security Studies (CSS), Heinrich Böll Foundation, Resource Security Institute (RSI), Research Centre for East European Studies (FSOE), 2011. Retrieved from http://www.isn.ethz.ch/isn/Digital-Library/Publications/Detail/?ots591=0c54e3b3-1e9c-be1e-2c24-a6a8c70 $60233 \& \operatorname{lng}=\mathrm{en} \& \mathrm{id}=135318$

Chitadze, N. (2012). Geopolitical Interests of Iran in South Caucasus and Georgian-Iranian, Relations. Journal of Social Sciences, 1(2), 5-12. 
Clawson, P. (2005). Eternal Iran. Coauthored with Michael Rubin. Palgrave Publication. http://dx.doi.org/10.1057/9781403977106

Collins, K., \& Owen, E. (2012). Islamic Religiosity and Regime Preferences: Explaining Support for Democracy and Political Islam in Central Asia and the Caucasus. Political Research Quarterly. http://dx.doi.org/10.1177/1065912912450554

Dolman, E. (2005). Astropolitik- Classical Geopolitics in the Space Age (Strategy and History Series). Taylor \& Francis e-Library.

Emerson, R. (2013). Post-hegemony and Gramsci: a bridge too far? Contemporary Politics, 19(4), 427-440. http://dx.doi.org/10.1080/13569775.2013.835114

Grove, T. (2012). Azerbaijan eyes aiding Israel against Iran. Reuters. Retrieved September 30, 2012, from http://www.reuters.com/article/2012/09/30/us-iran-israel-azerbaijan-idUSBRE88T05L20120930

Hafeznia, M. (2011). Principles and Concepts of Geopolitics. Papoli Publication, Second pub. Tehran, Iran.

http://www.britannica.com/EBchecked/topic/602385/Transcaucasia

Kaplan, R. (2014). The Caucasus: Laboratory of Geopolitics, January 2, 2014, realclearworld. Retrieved from $\mathrm{http}: / /$ www.realclearworld.com/articles/2014/01/02/the_caucasus_laboratory_of_geopolitics.html

Karami, J. (2005). Evolutions of Russia's Foreign Policy (Identity, Government and West). Tehran: Foreign Ministry Publication.

Khachatrian, H. (2006). Gas Prices Prompt Armenia to Debate Alliance with Russia. Retrieved January 29, 2006, from http://www.eurasianet.org/departments/insight/articles/eav013006.shtml

Lo, B. (2002). Russian Foreign Policy in the Post-Soviet Era: Reality, Illusion and Myth making (London: Palgrave Macmillan) pp. 18-19. http://dx.doi.org/10.1057/9781403920058

Ministry of Foreign Affairs of the republic of Armenia, Bilateral Relations with the Islamic Republic of Iran, Updated in 17 May 2012. Retrieved from http://mfa.am/en/country-by-country/ir/

Misera, A. (2013). The Southern Caucasus and Iranian influence, Directorate-General for External Policies Policy Department, Dg Expo, March 2013.

Mohammadi Malayeri, M. (1997). Persian culture in the transfer age from Sassanid's to Islam. Tous Poblication, Tehran, Iran

Mojtahedzade, P. (2001). Geopolitical Ideas and Iranian Facts. Ney Publication, Tehran, Iran.

Morozova, Na. (2009). Geopolitics, Eurasianism and Russian Foreign Policy Under Putin. Geopolitics, 14, 667686. http://dx.doi.org/10.1080/14650040903141349

Murinson, A. (2010). Iran Targets Azerbaijan, BESA Center Perspectives Paper No. 110, June 23, 2010. Retrieved from http://www.biu.ac.il/SOC/besa/perspectives110.html

National Statistics of Office of Georgia. (2012). Iranian Investments in Georgia. Retrieved July 10, 2012, from http://geostat.ge/?action=page\&p-id=136\&lang=GEO

Prozorov, S. (2008). Russian post-Communism and the End of History. Studies in East European Thought, 60, 207-209. http://dx.doi.org/10.1007/s11212-008-9054-y

Rabiee, H., GhrehBeygi, M., \& Mousavi, S. (2015). Hegemony of Iran in the Caspian-Central Asia Region from the perspective of Geopolitical Realities. United States of America Research Journal (USARJ), 5(1), 26-38.

Rubin, M. (2012). Iranian influence in the south Caucasus and the surrounding region, Testimony before the US House Committee on Foreign Affairs, 5 December 2012.

Russell, J. R. (1986). Armenia and Iran; Armenian Religion, Encyclopeadia Iranica, Vol. II, Fasc. 4, pp. 438-444.

Schaffer, B. (2003). Iran's role in the south Caucasus and Caspian region: diverging views of the U.S and Europe, Iran and its Neighbors: Diverging Views on a Strategic Region, German Institute for International and Security Affairs, July 2003.

Sharaf Alzia, H. (2008). Russia, Tehran: Center for Military Education of Sayyad Shirazi.

Shuri, M. (2003). Multilateral approaches in Russia's Foreign Policy. Tehran: Center for Eurasia Studies.

Smith, A. M. (2005). Russian Nationalist Movements and Geopolitical Thinking, Defence Academy of the United Kingdom: Conflict Studies Research Center, Russian Series, September 2005. 
Timothy, L. T. (2000). Russian National Interests and the Caspian Sea, Foreign Military Studies Office, Fort Leavenworth, KS. Perceptions December 1999-February 2000, Volume IV, Number 4 pp. 75-96.

Tsygankov, A. (2003). Mastering Space in Eurasia: Russia's Geopolitical Thinking after the Soviet Break-Up. Communist and Post-Communist Studies, 36, 101-127. http://dx.doi.org/10.1016/S0967-067X(02)00055-7

Vaezi, M. (2010). Evolutional Process of Shang Hi Corporation. Tehran: Center for Strategic Studies.

www.unep.org

\section{Copyrights}

Copyright for this article is retained by the author(s), with first publication rights granted to the journal.

This is an open-access article distributed under the terms and conditions of the Creative Commons Attribution license (http://creativecommons.org/licenses/by/3.0/). 